\title{
CAPITAL SOCIAL E RELACIONAMENTOS INTER E INTRARREGIONAIS EM ARRANJOS PRODUTIVOS LOCAIS: ESTUDO NO APL CALÇADISTA DE NOVA SERRANA/ MG
}

Artigo recebido em: 06/07/2014. Artigo aprovado em: 26/06/2015.

\author{
Ana Cláudia Azevedo - Universidade de São Paulo ${ }^{1}$ \\ Daniel Jardim Pardini - Universidade Fumec ${ }^{2}$ \\ Gustavo Leonardo Simão - Universidade Federal de Lavras3
}

Resumo: O Capital Social favorece o desenvolvimento competitivo das empresas por meio da construção de infraestrutura relacional e integração entre os atores presentes em núcleos comuns, como é o caso dos Arranjos Produtivos Locais (APLs). Uma vez que as empresas inseridas nos referidos núcleos se relacionam com atores internos e externos ao arranjo, o objetivo deste estudo foi analisar a formação e o desenvolvimento do Capital Social inter e intrarregional na perspectiva dos atores organizacionais no APL de Nova Serrana - MG. Objetivouse identificar características das relações estabelecidas pelos empresários inseridos no APL, considerando os contextos interno e externo ao arranjo, tendo como elemento mediador o Capital Social em suas três dimensões: estrutural, relacional e cognitiva (NAHAPIET; GOSHAL, 1998). Metodologicamente, recorreuse a uma pesquisa de natureza qualitativa, conduzida sob a forma de estudo de caso. Por acessibilidade, foram realizadas 10 entrevistas com empresários integrantes do APL. Como instrumento de pesquisa, utilizou-se um roteiro semiestruturado e o tratamento dos dados foi realizado por análise de conteúdo com o auxílio do software Atlas $T 1 \circledast$ versão 7.1.4. Os resultados da pesquisa evidenciaram que os empresários reconhecem o valor das práticas sociais, utilizam-nas em benefício de seus negócios e reconhecem a necessidade de se estabelecer relações de distintas naturezas e intensidade de vínculos dentro e fora do arranjo produtivo. Contudo, esbarram em algumas dificuldades, como as posturas individualistas e introspectivas fomentadas pelos elevados níveis de desconfiança. Em suma, a inserção no APL é percebida como favorável apenas pelas empresas mais integradas ao grupo.

Palavras-chave: Arranjo Produtivo Local; Capital Social; Relações Intrarregionais; Relações Inter-regionais.

\footnotetext{
${ }^{1}$ Endereço: Avenida Luciano Gualberto, 908, Butantã, São Paulo - SP, CEP: 05508-010. E-mail: anaklaudians@hotmail.com

${ }^{2}$ E-mail: pardinidaniel@hotmail.com

${ }^{3}$ E-mail: gustavoleu@hotmail.com
}

AZEVEDO, A. C.; PARDINI, D. J.; SIMÃO, G. L. Capital social e relacionamentos inter e intrarregionais em arranjos produtivos locais: estudo no APL calçadista de Nova Serrana/ MG. Revista de Empreendedorismo e Gestão de Pequenas Empresas, v.4, n.2, 2015. 
SOCIAL CAPITAL AND RELATIONSHIPS INTER AND INTRA REGION IN LOCAL PRODUCTIVE ARRANGEMENTS: STUDY IN LPA SHOEMAKER OF NOVA SERRANA/MG

\begin{abstract}
It is known that social capital contributes to the development of a potential competitiveness of enterprises through the construction of a relational infrastructure and an integration among the actors that are in networks or common core, as it is the case of Local Productive Arrangements-LPA. Once the companies that are inserted in these common cores relate to internal and external actors to the arrangement. The aim of this study was to analyze the formation and development of inter or intra Social Capital on a local region of Local Productive Arrangement of Nova Serrana - MG- Brazil from the perspective of organizational actors. In general terms, it is intended to identify characteristics of relationships established by entrepreneurs entered in LPA, based on the internal and external context to the arrangement, with the mediator and structuring element the Social Capital, in its three analytical dimensions: structural, relational and cognitive (NAHAPIET; GOSHAL, 1998). For that, methodologically resorted to the qualitative research, conducted in the form of case study. Were held 10 interviews with members of the APL. As a research instrument, it was used a semi-structured script and the data analysis was done by content analysis with the aid of Atlas TI® 7.1.4 software. The search results showed that entrepreneurs recognize the value of social and relational practices and they use them to benefit their business and recognize the need to establish relationships of different natures and intensity of linkages within and outside of the productive arrangement. However, the entrepreneurs run into some difficulties. The main one is introspective and individualistic attitudes fostered by high levels of distrusting. The insertion in LPA is perceived as positive only by companies that demonstrate higher levels of participation and integration into the group.
\end{abstract}

Keywords: Local Productive Arrangement; Social Capital; Intra regional relationships; Inter Regional Relationships.

\title{
Introdução
}

O aparecimento, sobretudo nas últimas décadas, de novos modelos e arranjos empresariais baseados na interação e no compartilhamento de valores e propósitos, seja no plano intra ou interorganizacional e na cooperação entre distintos agentes produtivos, vêm repercutindo nos estudos organizacionais. A capacidade de as empresas mobilizarem relações tornou-se central para o alcance de vantagem competitiva por parte dos atores organizacionais (RODRIGUES; CHILD, 2012). Esta capacidade é representada em grande parte pelo desenvolvimento de um ativo de natureza relacional denominado Capital Social.

AZEVEDO, A. C.; PARDINI, D. J.; SIMÃO, G. L. Capital social e relacionamentos inter e intrarregionais em arranjos produtivos locais: estudo no APL calçadista de Nova Serrana/ MG. Revista de Empreendedorismo e Gestão de Pequenas Empresas, v.4, n.2, 2015. 
As organizações que se destacam no mercado fazem melhor utilização do seu Capital Social por meio de suas conexões e relacionamentos, aumentando a capacidade de acessarem e de se beneficiarem de uma série de oportunidades e recursos que afetam os seus desempenhos (ADLER; KWON, 2002).

Para Cunha, Passador e Passador (2012), os relacionamentos sociais representam uma alternativa para se alcançar recursos que ora não poderiam ser acessados ou que seriam acessados com maior dificuldade se os atores estivessem atuando de forma isolada.

Com a ascensão da cooperação como alternativa ao modelo de inserção competitiva no mercado, a proliferação de arranjos produtivos locais (APLs) foi exponencialmente favorecida. Entretanto, sabe-se que a efetividade desses núcleos é condicionada à atuação articulada entre os diferentes atores que os compõem (empresas, instituições e governo) e à existência de elementos estruturantes, como confiança e cooperação entre eles (ADLER; KNOW, 2002). As relações ocorridas entre empresas e entidades presentes em determinado arranjo produtivo são permeadas de dificuldades, sobretudo, em função da competitividade instaurada entre as próprias empresas presentes no núcleo (MORE; VALLE; VILELLA, 2007).

Apesar disso, as pesquisas que se dedicam a identificar na perspectiva de cada ator organizacional, como esses administram seus relacionamentos em prol do desenvolvimento de seus negócios ainda são relativamente poucas. Portanto, como ocorre a formação e o desenvolvimento do Capital Social inter e intrarregional em arranjos produtivos locais, essa questão permanece aberta.

Assim, este estudo buscou contribuir para a base de conhecimento, explorando as concepções dos gestores sobre as relações estabelecidas dentro e fora do APL, no intuito de compreender as motivações e as dificuldades, e captar os benefícios decorrentes dessas relações para o desenvolvimento de seus negócios, tendo como elemento mediador e estruturante o Capital Social, em suas três dimensões: estrutural, relacional e cognitiva (NAHAPIET; GOSHAL, 1998).

Em suma, por meio da associação das temáticas: Capital Social, Aglomerações Produtivas e Relacionamentos Organizacionais, buscou-se compreender o real motivo pelo qual as empresas se conectam, de que forma 
utilizam a interação social para a atuação organizacional e, principalmente, como se dão essas interações dentro (intrarregional) e fora (inter-regional) dos arranjos produtivos locais, especificamente do Arranjo Produtivo Calçadista de Nova Serrana - MG, considerando a perspectiva de cada ator social.

\section{Capital Social}

O termo Capital Social é utilizado de maneira ampla na literatura organizacional e nos vários ramos das ciências sociais, expressando diferentes percepções e sentidos (VALE, 2007; MARCONATTO; PEDROZO, 2011). No entanto, apesar de sua natureza multidimensional e em função de suas origens sociológicas, há um predomínio na literatura de que o conceito de Capital Social remete a um ativo decorrente das relações sociais (MARTELETO; SILVA, 2004; VALE, 2007; GOBB, 2010).

No aspecto organizacional, a teoria do Capital Social sugere que as empresas criem e sejam incorporadas em uma rede de relações que podem oferecer acesso a recursos e oportunidades de diferentes naturezas (VALE, 2007). Nesta vertente, Portes (1998) caracteriza o Capital Social como um ativo decorrente das interações ocasionadas entre os participantes de uma determinada rede que permite ou facilita o acesso a recursos, apoios e relações para alcance dos objetivos organizacionais.

Para Nahapiet e Goshal (1998), a conjectura central da teoria do Capital Social é de que redes de relacionamento constituem um recurso valioso que habilita os membros dessas redes a obterem recursos de outros participantes da referida estrutura.

Nesta mesma perspectiva, Lin (2001, p. 12) define Capital Social como "os recursos incorporados em uma estrutura social que são acessados e mobilizados em ações intencionais". Para o autor, o Capital Social dinamiza a troca de informações na rede por meio da influência exercida no processo de interação entre os agentes. Dessa forma, favorece o estabelecimento de credenciais sociais, além de reforçar o reconhecimento dos atores que formam essa rede. O Capital 
Social figura como um investimento em socialização que almeja retorno, podendo este ser tangível ou virtual, desde que auxilie os atores no alcance de seus objetivos (LIN, 2001).

Considerando as diferentes contextualizações do termo Capital Social presentes na literatura, cumpre ressaltar que não é intuito deste estudo promover um debate aprofundado acerca dos distintos conceitos a ele associados. Portanto, para melhor operacionalização e compreensão deste texto, considerando as nuances para se analisar o Capital Social no núcleo de uma aglomeração produtiva e o contexto proposto para o desenvolvimento deste estudo, sempre que se empregar o termo Capital Social, será considerada a abordagem econômica do conceito. Seguindo essa abordagem, Nahapiet e Ghoshal (1998) definem o Capital Social como "um ativo de natureza relacional decorrente da soma dos recursos reais ou potenciais imersos em/disponíveis, através, e derivados das redes de relacionamentos possuídas por um indivíduo ou unidade social" (NAHAPIET; GHOSHAL, 1998, p. 243).

De acordo com Amato Neto (2000), uma das principais tendências da economia moderna, sob o marco da globalização e da reestruturação industrial, diz respeito às relações intra e interempresas. Ao se considerar que o Capital Social é produzido pela estrutura das relações sociais e que pode ser mobilizado para facilitar ações, ele é reconhecido como a capacidade de uma empresa em acessar recursos, apoios e relações para o desenvolvimento de suas atividades, iniciativas ou empreendimentos e solução de problemas, e dinâmica diretamente relacionada à realidade proposta para os arranjos produtivos locais.

Diante do exposto e seguindo a lógica deste estudo, foram estabelecidas as seguintes perspectivas para observação do Capital Social no âmbito dos arranjos produtivos locais (Quadro 1). 
Quadro 1 - Perspectivas de análise do Capital Social

\begin{tabular}{|c|c|c|c|}
\hline $\begin{array}{l}\text { Nível das } \\
\text { relações }\end{array}$ & Foco & $\begin{array}{l}\text { Esquema } \\
\text { gráfico }\end{array}$ & $\begin{array}{l}\text { Dimensões de } \\
\text { Análise do } \\
\text { Capital Social }\end{array}$ \\
\hline $\begin{array}{l}\text { Inter- } \\
\text { regionais }\end{array}$ & $\begin{array}{l}\text { Analisa as relações estabelecidas } \\
\text { por cada ator (indiferente da } \\
\text { localização), suas principais } \\
\text { características e a que recursos } \\
\text { dão acesso. } \\
\text { As organizações são analisadas } \\
\text { nas suas inter-relações com } \\
\text { outras organizações dentro e fora } \\
\text { do APL. }\end{array}$ & & $\begin{array}{l}\text { - Estrutural } \\
\text { - Relacional } \\
\text { - Cognitiva }\end{array}$ \\
\hline $\begin{array}{l}\text { Intrarregionai } \\
\mathrm{s}\end{array}$ & $\begin{array}{l}\text { Analisa as relações estabelecidas } \\
\text { apenas no âmbito do APL (entre } \\
\text { os atores presentes no núcleo) } \\
\text { também no intuito de levantar } \\
\text { suas principais características e a } \\
\text { quais recursos dão acesso. } \\
\text { São analisadas as relações } \\
\text { ocorridas entre as organizações } \\
\text { pertencentes ao APL, ou seja, } \\
\text { nesta perspectiva se consideram } \\
\text { os aspectos internos das relações } \\
\text { ocorridas dentro do núcleo. }\end{array}$ & & $\begin{array}{l}\text { - } \text { Estrutural } \\
\text { - Relacional } \\
\text { - Cognitiva }\end{array}$ \\
\hline $\begin{array}{l}\text { Inter/ } \\
\text { intrarregionai } \\
\text { s }\end{array}$ & $\begin{array}{l}\text { Analisa as relações estabelecidas } \\
\text { dentro do APL (entre os atores) e } \\
\text { as relações estabelecidas pelo } \\
\text { APL com o mercado (enquanto } \\
\text { uma representatividade coletiva), } \\
\text { e como as empresas se } \\
\text { beneficiam dessas relações. } \\
\text { Analisa o relacionamento do APL } \\
\text { no âmbito de sua coletividade com } \\
\text { outros atores do mercado. } \\
\text { Considera-se a interação entre as } \\
\text { empresas presentes no núcleo e a } \\
\text { representatividade do núcleo, } \\
\text { enquanto coletividade de } \\
\text { empresas no mercado. }\end{array}$ & & $\begin{array}{ll}\text { - } & \text { Estrutural } \\
\text { - } & \text { Relacional } \\
\text { - } & \text { Cognitiva }\end{array}$ \\
\hline
\end{tabular}

Fonte: Os autores (2015)

Para Adler e Kwon (2002) o Capital Social pode ser interpretado sobre três perspectivas distintas em relação ao seu núcleo de centralidade: interna, externa e interna/externa. De acordo com os autores, a perspectiva externa diz respeito às relações que um ator específico mantém com outros atores, indiferentemente se

AZEVEDO, A. C.; PARDINI, D. J.; SIMÃO, G. L. Capital social e relacionamentos inter e intrarregionais em arranjos produtivos locais: estudo no APL calçadista de Nova Serrana/ MG. Revista de Empreendedorismo e Gestão de Pequenas Empresas, v.4, n.2, 2015. 
estão presentes ou não em um núcleo comum. Essas relações são identificadas aqui como relações inter-regionais. A segunda perspectiva proposta pelos autores refere-se à estrutura das relações entre atores dentro de uma coletividade (ADLER; KOWN, 2002). Consideram-se, na perspectiva interna, as relações intrarregionais ocorridas no núcleo do APL. A terceira perspectiva associa as duas anteriores, representando, portanto, para fins deste estudo, as relações ocorridas dentro do APL e fora dele.

\section{Dimensões do Capital Social propostas por Nahapiet e Goshal (1998)}

Nahapiet e Ghoshal (1998) propuseram três dimensões para análise do Capital Social: cognitiva, estrutural e relacional. Embora os autores apresentem essa proposta de categorização, afirmam que as três dimensões encontram-se altamente relacionadas, o que não inviabiliza ou mesmo invalida a classificação, pois sua complementaridade e interdependência facilitam a compreensão do construto.

Conforme Nahapiet e Goshal (1998), a dimensão estrutural refere-se ao padrão de conexões entre os atores, isto é, como e com quem um determinado ator se relaciona. A principal característica dessa dimensão é a configuração da rede, tanto em aspectos de densidade, como de conectividade e hierarquia (NAHAPIET; GOSHAL, 1998).

Em termos gerais, a dimensão estrutural traz aspectos de nível micro, como a força das relações, e aspectos de nível macro, como a configuração da rede. Wegner e Maehler (2012) sintetizam que os elementos característicos da dimensão estrutural são o número de contatos de um ator, a diversidade dos contatos, a configuração e a estabilidade da rede, e a posição do ator na rede, ou seja, com quem ele tem contato e como ele ocorre.

Por outro lado, a dimensão cognitiva explora os significados que são difundidos pelos atores e entre os atores da rede (NAHAPIET; GOSHAL, 1998). Dessa forma, relacionam-se às interpretações e aos sistemas de significados, 
incluindo a linguagem, os códigos e as narrativas compartilhados pelos atores (NAHAPIET; GOSHAL, 1998).

$\mathrm{Na}$ concepção de Régis (2005), em função de suas características, a dimensão cognitiva facilita e fornece condições para o desenvolvimento do capital intelectual, por fornecer as condições necessárias para a troca e o compartilhamento de saberes entre os atores. Nessa perspectiva de análise, Wegner e Maehler (2012) afirmam que à medida que os atores partilham objetivos, compreensões e uma cultura comum, subjetivamente são estabelecidas normas de comportamento genéricas que influenciam diretamente a conduta dos relacionamentos.

Por fim, ao abordarem a dimensão relacional, Nahapiet e Goshal (1998) tiram o foco da configuração da rede de relacionamentos e o depositam sobre suas características e o conteúdo. Para os autores, essa dimensão recai sobre o tipo de relações que atores ou unidades sociais desenvolvem, referindo-se a cada relação individual de um ator com outros atores da rede e considerando, além do conteúdo transacionado entre os atores, os papéis que eles podem assumir, tais como amigos, informantes, confidentes, professores e técnicos (NAHAPIET; GOSHAL, 1998).

Nahapiet e Goshal (1998) afirmam ainda que a confiança é um elemento precursor para dinamizar as relações, tornando-se um aspecto relevante de observação ao se avaliar a dimensão relacional do Capital Social. Atores que desenvolvem um alto grau de confiança e confiabilidade estão mais propícios a se apropriarem de conhecimentos, informações e outras formas de recursos disponíveis nas suas relações, porque uma atmosfera de confiança contribui para a troca de conhecimentos entre parceiros, por levá-los a sentirem que não precisam proteger a si próprios do comportamento oportunista dos outros.

Diante das dimensões de análise propostas, Wegner e Maehler (2010) observam um viés relativo à teoria do Capital Social. Este pode referir-se tanto à rede em si (conexões entre os atores) quanto aos ativos que podem ser mobilizados por meio dessa rede. Assim, ao se avaliar a configuração de uma rede, assume-se um foco estrutural. Por outro lado, ao se evidenciar como e quais são 
os ativos mobilizados por meio da referida rede, ela passa a ser avaliada pelas óticas cognitiva e relacional.

Tais apontamentos remetem a um impasse relativo à Teoria do Capital Social, qual seja sua indissociabilidade da Teoria das Redes Sociais. Diante dessa distinção, esse estudo não pretendeu evidenciar em profundidade a dimensão estrutural do conceito de Capital Social, por meio do mapeamento e da identificação pontual das relações dos atores em caráter estrutural. Em contrapartida, seu foco recaiu sobre uma perspectiva cognitiva e relacional do Capital Social, centrada em avaliar os benefícios decorrentes das relações sociais que efetivamente compõem os ativos originários do Capital Social no núcleo dos arranjos produtivos locais.

\section{Arranjos produtivos locais}

Contemporaneamente, diversas são as terminologias utilizadas para denominar as aglomerações produtivas, como: economias regionais, redes empresariais, sistemas produtivos locais, clusters, distritos industriais e arranjos produtivos locais.

Apropriando-se da definição moderna de Arranjo Produtivo Local (APL), Lastres e Cassiolato (2005) definem tais estruturas como aglomerações territoriais de agentes econômicos, políticos e sociais, com foco em um conjunto específico de atividades econômicas e com relações de interdependência, de articulação e de vínculos consistentes.

No ambiente contemporâneo, os APLs são considerados redutos de cooperação, nos quais a interação interorganizacional torna-se a "chave" para o desempenho empresarial, reforçando a eficácia de atuação dos atores participantes do núcleo (CASTELLS, 2005). Para Amorim (1998), a concentração territorial pode encorajar a cooperação, a aprendizagem e a troca de informações entre as empresas tornando-as mais eficientes e competitivas.

Diante da caracterização dos APLs, Lundvall (1988) afirma que as empresas alcançam competitividade pelas interações realizadas com outras firmas. 
Ferraz, Gobb e Lima (2011) corroboram esse posicionamento ao avaliar que a atuação em APLs favorece as organizações, especialmente aquelas de pequeno porte, tanto na conciliação entre economia de escala e flexibilidade, como na redução de custos e/ou no estímulo às ações empreendedoras e de inovação.

Para Leite, Lopes e Silva (2009), a vantagem competitiva oferecida pelos APLs consiste no relacionamento estabelecido pelos atores neles envolvidos. Conforme afirmam Ferraz, Gobb e Lima (2011), com base nos elementos característicos do conceito de arranjo produtivo local, na sua concepção ideal, essas estruturas são tão mais consistentes na medida em que seus atores desenvolvem Capital Social.

Nesta vertente, Albagli e Maciel (2003) também avaliam que os componentes do Capital Social favorecem os processos de inovação, de aprendizado interativo, e criação e compartilhamento de conhecimentos, no núcleo do arranjo, gerando benefícios econômicos e sociais para as empresas, tais como: maior facilidade de compartilhamento de informações e conhecimento; criação de ambientes propícios ao empreendedorismo, contribuindo para o aumento de competitividade e sobrevivência sustentada das organizações dos arranjos; melhor coordenação e coerência de ações (governança), processos de tomada de decisão coletivos, bem como maior estabilidade organizacional, o que também contribui para diminuir custos; maior conhecimento mútuo entre os atores, reduzindo os riscos do oportunismo e favorecendo um maior compromisso com relação ao grupo.

Sugahara e Vergueiro (2011) complementam que as interações sociais, provedoras do Capital Social, podem incorrer na potencialização de diferenciais competitivos recíprocos, representados pela difusão da informação e pela redução das restrições de tempo e de espaço. Nessa linha, um APL configura-se como um ambiente favorável para a permuta de informações, conhecimentos, habilidades e recursos (MORE; VALLE; VILLELA, 2007).

Frente ao exposto, mesmo que as empresas envolvidas nos APLs sejam caracterizadas como incipientes em seu nível de organização, o ambiente em si permite que haja interações entre os atores e o contexto no qual estão inseridos, estabelecendo, assim, condições favoráveis para o alcance de ganhos coletivos e 
individuais em termos organizacionais e sociais (AMARAL FILHO, 2002). No entanto, a interação entre os atores sem um complexo ordenamento das relações não representa por si só a garantia de efetividade de um APL (CASTELLS, 2005).

Segundo Sugahara e Vergueiro (2011), as atividades oriundas de um APL potencializam a construção de interações entre os agentes locais (empreendedores) e destes com agentes externos (universidades, prefeituras, entre outros), melhorando a capacidade competitiva das empresas. Nesse aspecto, o território, mais que um simples alicerce físico para as relações entre indivíduos, empresas, entidades e Estado, possui uma textura social, uma organização complexa feita por laços que vão muito além de suas propriedades naturais (VALE, 2007).

O percurso metodológico adotado para a condução deste estudo será descrito no tópico seguinte.

\section{Percurso metodológico}

Quanto à sua abordagem, esta pesquisa caracterizou-se como qualitativa (CRESWELL, 2010). O percurso metodológico percorrido para investigação do problema estudado iniciou-se com a revisão de literatura envolvendo os construtos: Capital Social e Aglomerações Produtivas, que permitiu uma melhor compreensão dessas temáticas na perspectiva dos diversos pesquisadores.

Para Creswell (2010), os pesquisadores qualitativos tendem a coletar dados para seus estudos no campo, ou seja, no local em que os participantes vivenciam a questão. Assim, na tentativa de compreender a dinâmica das relações ocasionadas no APL de Nova Serrana - MG e de correlacioná-las à Teoria do Capital Social, na perspectiva das relações inter e intrarregionais, a estratégia adotada nesta pesquisa foi o estudo de caso, elegendo-se como ambiente de estudo o Arranjo Produtivo Local de Nova Serrana - MG (YIN, 2001).

A pesquisa abrangeu uma amostra caracterizada por acessibilidade, contemplando 10 atores inseridos no APL de Nova Serrana-MG. Para seleção dos atores participantes considerou-se como critérios de inclusão: empresas afiliadas à 
entidade gestora do APL, o Sindinova, e como critério de exclusão, empresas com tempo de filiação à entidade inferior a doze meses.

A coleta de dados foi concretizada por meio de entrevistas diretas e semiestruturadas realizadas individualmente no período de novembro a dezembro de 2013 (FLICK, 2009). No roteiro foram inseridas perguntas com o objetivo de levantar os principais aspectos do contexto relacional nas empresas presentes no APL de Nova Serrana - MG, além de avaliar a gestão dos relacionamentos nas três dimensões analíticas do Capital Social, considerando, ainda, o quesito da regionalidade ao diferenciar as relações ocasionadas dentro e fora do APL (NAHAPIET; GOSHAL, 1998).

Para interpretação dos dados, utilizou-se a técnica da análise de conteúdo proposta por Bardin (2010), seguindo as fases de: (a) organização; (b) codificação; (c) categorização e (d) inferência sobre o conteúdo do texto analisado. Na etapa de categorização, as principais categorias analíticas utilizadas nas interpretações decorreram das dimensões do Capital Social, propostas por Nahapiet e Goshal (1998): estrutural, relacional e cognitiva.

Após as entrevistas, as narrativas foram transcritas literalmente e depois do aceite dos entrevistados, todos os textos foram agrupados em uma unidade hermenêutica do software Atlas $T 1{ }^{\circledR}$ versão 7.1.4, ferramenta computacional indicada para apoiar a análise de dados qualitativos (FERREIRA et al., 2012; FLICK, 2009).

Por fim, buscando desenhar uma análise dos dados que atendesse aos pressupostos teórico-metodológicos, optou-se por utilizar como ferramentas analíticas as sentenças retiradas das entrevistas, conforme o modelo teóricoanalítico descrito a seguir.

\section{Modelo teórico-analítico}

Conforme mencionado anteriormente, a fim de contribuir com o entendimento da análise realizada, ela foi dividida em três tópicos que obedeceram ao padrão das dimensões analíticas do Capital Social propostas por Nahapiet e 
Goshal (1998): Relacional, Cognitiva e Estrutural. Para sistematização dos horizontes de averiguação, as categorias propostas em nível macro foram desmembradas e aglomeradas em outras vertentes analíticas, constituindo subcategorias de análise, conforme apresentado no Quadro 2.

Levantou-se por meio das associações verbais, o sentido e os significados que os atores organizacionais atribuem às suas realidades sociais e como essas percepções interferem e definem posturas e ações no processo de interação dentro e fora do arranjo produtivo.

Quadro 2 - Categorização das dimensões de análise

\begin{tabular}{|c|c|c|}
\hline Categoria & Subcategoria & $\begin{array}{c}\text { Principais códigos levantados nas } \\
\text { entrevistas }\end{array}$ \\
\hline \multirow{3}{*}{$\begin{array}{l}\text { Dimensão } \\
\text { Relacional }\end{array}$} & Integração & $\begin{array}{l}\text { Abertura, parceria, vantagem, } \\
\text { conjunto, contato, envolvimento, } \\
\text { equipe, honestidade, amizade, } \\
\text { confiança, entrosamento, } \\
\text { transparência, precário, informal, } \\
\text { fechado, sozinho. }\end{array}$ \\
\hline & Dificuldades & $\begin{array}{l}\text { Disputa, isolamento, panelinha, } \\
\text { desunião, concorrência, competição, } \\
\text { desconfiar, cópia, resistência, } \\
\text { interferir, complicacão. }\end{array}$ \\
\hline & Expectativa & $\begin{array}{l}\text { Vital, necessidade, apoio, auxílio, } \\
\text { desenvolver, suporte, facilitar, ajudar, } \\
\text { ampliar, benefício, facilidade, } \\
\text { incentivo, cultivar, fortalecer. }\end{array}$ \\
\hline \multirow[t]{2}{*}{ Dimensão Cognitiva } & $\begin{array}{l}\text { Recursos } \\
\text { compartilhados }\end{array}$ & $\begin{array}{l}\text { Acesso, diálogo, conhecimento, } \\
\text { inovação, recursos, pesquisa, } \\
\text { experiências, informação, } \\
\text { capacitação, ação, aprendizagem, } \\
\text { desenvolvimento. }\end{array}$ \\
\hline & Resultados & $\begin{array}{l}\text { Aprendizagem, agilidade, satisfação, } \\
\text { eventos, vendas, ganhar, } \\
\text { investimento, oportunidade. }\end{array}$ \\
\hline \multirow{3}{*}{ Dimensão Estrutural } & Atores & $\begin{array}{l}\text { Arranjo, sindicato, SENAI, governo, } \\
\text { prefeitura, IEL, FIEMG, SEBRAE, } \\
\text { Credinova, APL, Faculdade. }\end{array}$ \\
\hline & Papéis & $\begin{array}{l}\text { Fornecedor, cliente, sindicato, } \\
\text { vendedor, funcionário, fabricante, } \\
\text { amigo, representante, parceiro, pai, } \\
\text { irmão, família, banco, assessoria, } \\
\text { banca, ateliê, indústria. }\end{array}$ \\
\hline & Localização & $\begin{array}{l}\text { Próximo, distante, dentro, mundo, } \\
\text { local, perto, Nova Serrana, fora. }\end{array}$ \\
\hline
\end{tabular}

Fonte: Os autores (2015).

AZEVEDO, A. C.; PARDINI, D. J.; SIMÃO, G. L. Capital social e relacionamentos inter e intrarregionais em arranjos produtivos locais: estudo no APL calçadista de Nova Serrana/ MG. Revista de Empreendedorismo e Gestão de Pequenas Empresas, v.4, n.2, 2015. 
Dessa forma, a categoria da Dimensão Relacional ficou organizada a partir do tripé: características da integração, dificuldades e expectativas (benefícios esperados das relações). Essa divisão foi realizada tendo em vista que a Dimensão Relacional busca identificar o tipo de relacionamento que os atores desenvolvem uns com os outros, ressaltando o conteúdo e as características dessas relações que terminam por incorrer em um emaranhado de interações.

Tais interações permitem aos atores acessar recursos que podem ser convertidos em benefícios para a organização, o que acarreta expectativas sobre o que alcançar ao se relacionar. No entanto, também podem representar desafios decorrentes de certas dificuldades ocasionadas no estabelecimento de tais relações.

A categoria da Dimensão Cognitiva amparou-se nos quesitos: recursos compartilhados e resultados, por entender essa como uma dimensão em que o alinhamento de significados partilhados entre os atores representa a troca de informações e a definição de posturas de atuações, se não similares, ao menos coerentes entre si. As compreensões e os significados originários das trocas sociais orientam as decisões e os comportamentos dos atores, uma vez que o nível informacional é um dos fatores determinantes da atuação e esta, por sua vez, é necessária para a promoção de resultados.

Por fim, a categoria da Dimensão Estrutural, vinculada ao contexto dos padrões de contatos e estrutura das redes de relacionamentos também se formatou a partir de três vertentes: os atores, os papéis assumidos e a localização. O nível de familiaridade e de confiança presente nos relacionamentos varia conforme a localização dos atores. Para determinadas relações, faz-se necessário um maior nível de proximidade e confiança. Para outras, no entanto, o ideal é se relacionar com o externo e o distante, porque esse pode ser detentor de informações que não são comuns a determinados núcleos (GRANOVETTER, 1973).

Os papéis assumidos nessas relações e a localização desses atores enquanto componentes estruturais da rede serviram para a avaliação de como se configuram as relações no APL de Nova Serrana - MG, ainda que não se tenha feito um mapeamento formal das relações ocasionadas dentro e fora do arranjo. 
Frente à categorização adotada, a Tabela 1 apresenta a frequência de aparecimento das famílias de categorias em cada uma das entrevistas realizadas para este estudo. Por meio dela, avaliou-se a relevância das categorias escolhidas, assim como a representatividade de cada uma delas.

Tabela 1 - Frequência das famílias de categorias nas entrevistas organizada através do Atlas TI 7.1.4

\begin{tabular}{|c|c|c|c|c|c|c|c|c|c|c|c|c|}
\hline \multirow{2}{*}{ Famílias de Categorias } & \multicolumn{11}{|c|}{ Entrevistas } & \multirow{2}{*}{ TOTAL } \\
\hline & E1 & E2 & E3 & E4 & E5 & E6 & E7 & E8 & E9 & E10 & E11 & \\
\hline INTEGRAÇÃO & 12 & 32 & 24 & 12 & 10 & 33 & 41 & 36 & 20 & 15 & \multirow{8}{*}{$\begin{array}{l}\text { 음 } \\
\text { o } \\
0 \\
\frac{0}{0} \\
\frac{0}{0} \\
\frac{0}{2} \\
\end{array}$} & 235 \\
\hline DIFICULDADES & 2 & 8 & 6 & 1 & 4 & 5 & 12 & 17 & 4 & 2 & & 61 \\
\hline MOTIVAÇÃO & 8 & 20 & 9 & 6 & 7 & 16 & 27 & 19 & 17 & 7 & & 136 \\
\hline RECURSOS COMPART. & 8 & 22 & 14 & 9 & 4 & 12 & 36 & 32 & 15 & 7 & & 159 \\
\hline RESULTADOS & 5 & 17 & 8 & 8 & 2 & 9 & 20 & 22 & 13 & 5 & & 109 \\
\hline ATORES & 7 & 28 & 23 & 6 & 9 & 20 & 29 & 36 & 19 & 5 & & 182 \\
\hline PAPÉIS & 13 & 38 & 19 & 12 & 7 & 19 & 47 & 31 & 30 & 15 & & 231 \\
\hline LOCALIZAÇÃO & 4 & 10 & 7 & 7 & 5 & 12 & 7 & 18 & 14 & 4 & & 88 \\
\hline $\begin{array}{c}\text { Total de palavras } \\
\text { analisadas }\end{array}$ & 59 & 175 & 110 & 61 & 48 & 126 & 219 & 211 & 132 & 60 & - & 1.201 \\
\hline $\begin{array}{c}\text { Total de palavras do } \\
\text { documento }\end{array}$ & 770 & 1.822 & 589 & 1.026 & 859 & 577 & 1.206 & 2.303 & 2.324 & 1.440 & - & 12.916 \\
\hline $\begin{array}{c}\text { \% do documento } \\
\text { analisado }\end{array}$ & $8 \%$ & $10 \%$ & $19 \%$ & $6 \%$ & $6 \%$ & $22 \%$ & $18 \%$ & $9 \%$ & $6 \%$ & $4 \%$ & - & $9 \%$ \\
\hline
\end{tabular}

Fonte: Os autores(2015).

A tabela demonstra que a análise de dados atingiu e utilizou de 04\% a 22\% dos dados coletados e apresentou o somatório total da análise de dados, ou seja, a apreciação de 12.916 palavras em todo o corpus de análise. A análise detalhada e discussão do conteúdo das entrevistas encontram-se no capítulo seguinte.

\section{Resultados e discussões: O APL de Nova Serrana}

O Arranjo Produtivo Local de Nova Serrana - MG está localizado na região centro-oeste do Estado de Minas Gerais. Capitaneado por Nova Serrana, tem ainda como participantes os municípios circundantes de Perdigão, Araújos, São Gonçalo do Pará, Bom Despacho, Conceição do Pará, Divinópolis, Igaratinga, Leandro Ferreira, Onça do Pitangui, Pará de Minas e Pitangui.

De acordo com informações levantadas junto à Secretaria de Estado de Fazenda de Minas Gerais, em novembro de 2013, estavam presentes e em 
atividade no arranjo, 3.187 empreendimentos registrados sob os CNAEs 1540-8/00 - Fabricação de partes para calçados de qualquer material e 1539-4/00 Fabricação de calçados de materiais não especificados anteriormente que, segundo a Associação dos Contadores Locais, representam as duas principais categorias adotadas para registro das empresas do segmento calçadista. Do total de empresas no arranjo, 2.552 encontram-se em Nova Serrana - MG.

O comitê gestor do APL é coordenado pelo Sindicato Intermunicipal das Indústrias de Calçados de Nova Serrana (Sindinova) e composto por diversas entidades representativas dos setores empresarial, governamental e educacional, como FIEMG, ABICALÇADOS, SEBRAE e Prefeitura Municipal. De acordo com informações coletadas junto à gerente administrativa da entidade, em 2013, encontravam-se regularmente afiliadas ao sindicato um quantitativo de 417 empresas situadas em Nova Serrana e região.

Das empresas afiliadas ao Sindinova, conforme mencionado anteriormente, foram entrevistados 10 empresários distintos. Para sistematizar a análise e resguardar suas identidades, seus nomes foram substituídos por códigos de identificação: "Entrevistado 1", "Entrevistado 2", e assim sucessivamente. O perfil dos entrevistados que compuseram a amostra pode ser observado no Erro! Fonte de referência não encontrada.

Quadro 3 - Perfil dos entrevistados

\begin{tabular}{|c|c|c|c|l|r|c|}
\hline Ident. & $\begin{array}{c}\text { Início } \\
\text { Atividades }\end{array}$ & $\begin{array}{c}\text { № de } \\
\text { colab. }\end{array}$ & \multicolumn{2}{|c|}{$\begin{array}{c}\text { Tipo de produto } \\
\text { fabricado }\end{array}$} & $\begin{array}{c}\text { Produção } \\
\text { diária (pares) }\end{array}$ & $\begin{array}{c}\text { Vínculo } \\
\text { Sindinova (anos) }\end{array}$ \\
\hline E 1 & $18 / 03 / 2012$ & 9 & Feminino & Adulto & 200 & 1 \\
\hline E 2 & $03 / 07 / 1986$ & 13 & Masculino & Adulto & 200 & 10 \\
\hline E 3 & $17 / 06 / 1988$ & 28 & Misto & Infantil & 1200 & 9 \\
\hline E 4 & $24 / 05 / 1991$ & 106 & Misto & Adulto & 1200 & 10 \\
\hline E 5 & $07 / 08 / 2012$ & 8 & Feminino & Adulto & 100 & 1 \\
\hline E 6 & $31 / 07 / 2008$ & 17 & Masculino & Adulto & 320 & 1 \\
\hline E 7 & $12 / 08 / 1999$ & 75 & Feminino & Adulto & 1300 & 10 \\
\hline E 8 & $18 / 10 / 1982$ & 180 & Feminino & Adulto & 1200 & 12 \\
\hline E 9 & $08 / 08 / 1983$ & 260 & Misto & Adulto & 2500 & 13 \\
\hline E 10 & $25 / 01 / 1990$ & 180 & Misto & Misto & 2200 & 20 \\
\hline
\end{tabular}

Fonte: Os autores (2015). 
Como é possível verificar, as empresas mais antigas possuem um número maior de colaboradores e, por conseguinte, uma maior capacidade produtiva, exceto o Entrevistado 3, que possui um número menor de colaboradores quando comparado aos demais, em função do produto fabricado e de ter parte de seu processo produtivo terceirizado.

É possível observar também que as empresas mais antigas, em sua maioria, possuem maior estabilidade mercadológica em termos de volume de produção, permitindo, assim, avaliar que o tempo facilita a atuação das empresas no mercado. Das empresas visitadas, quatro produzem calçados femininos, duas produzem calçados masculinos e quatro trabalham com os dois públicos. Dessas mesmas empresas, oito produzem calçados adultos, uma produz exclusivamente calçados infantis e uma alterna entre as linhas adulto e infantil.

A maior concentração na produção de calçados femininos adultos reflete o perfil de produção da cidade, qual seja, calçados esportivos e as chamadas modinhas (modelos baseadas em tendências que apresentam variação temporal predefinida), com estações bem definidas e grande volatilidade e variedade de coleções.

\section{Capital social e as relações inter e intrarregionais no APL de Nova Serrana - MG: Dimensões do Capital Social}

Ao se buscar compreender, por meio das dimensões do Capital Social, propostas por Nahapiet e Goshal (1998) como sendo Relacional, Cognitiva e Estrutural, as práticas interativas realizadas pelos atores organizacionais dentro e fora do APL de Nova Serrana - MG, observou-se na Dimensão Relacional, que os gestores reconhecem a necessidade de se estabelecer relações e apresentam expectativas quanto aos benefícios que podem alcançar por meio dessas relações. Termos como "vital", "necessidade", "apoio", "auxílio e "suporte" são mapeados nessa análise.

Porém, os níveis de desconfiança e competição presentes dentro do APL inviabilizam as trocas sociais, favorecendo posturas mais individualistas e isoladas que dificultam a interação. Tais inferências decorrem do emprego de termos pelos 
entrevistados, tais como "competição", "disputa", "desunião", "resistência", "desconfiar", "prejudica" e outros que podem ser observados na grade de análise e nos trechos das entrevistas.

No meu caso, os relacionamentos são de vital importância; só para você entender, grande parte dos meus problemas aqui na fábrica, resolvo com base nos relacionamentos, trocando ideia com outros fabricantes amigos ou com meus representantes (ENTREVISTADO 01).

Olha, umas das dificuldades que nós encontramos para formar novas relações e as velhas também é a confiança. Aqui na empresa costumamos dizer que "não temos concorrentes e sim parceiros", mas o que a gente vê lá fora não é bem isso, é só "cobra comendo cobra", entende? Se bobear, puxam seu tapete, infelizmente (ENTREVISTADO 03). 


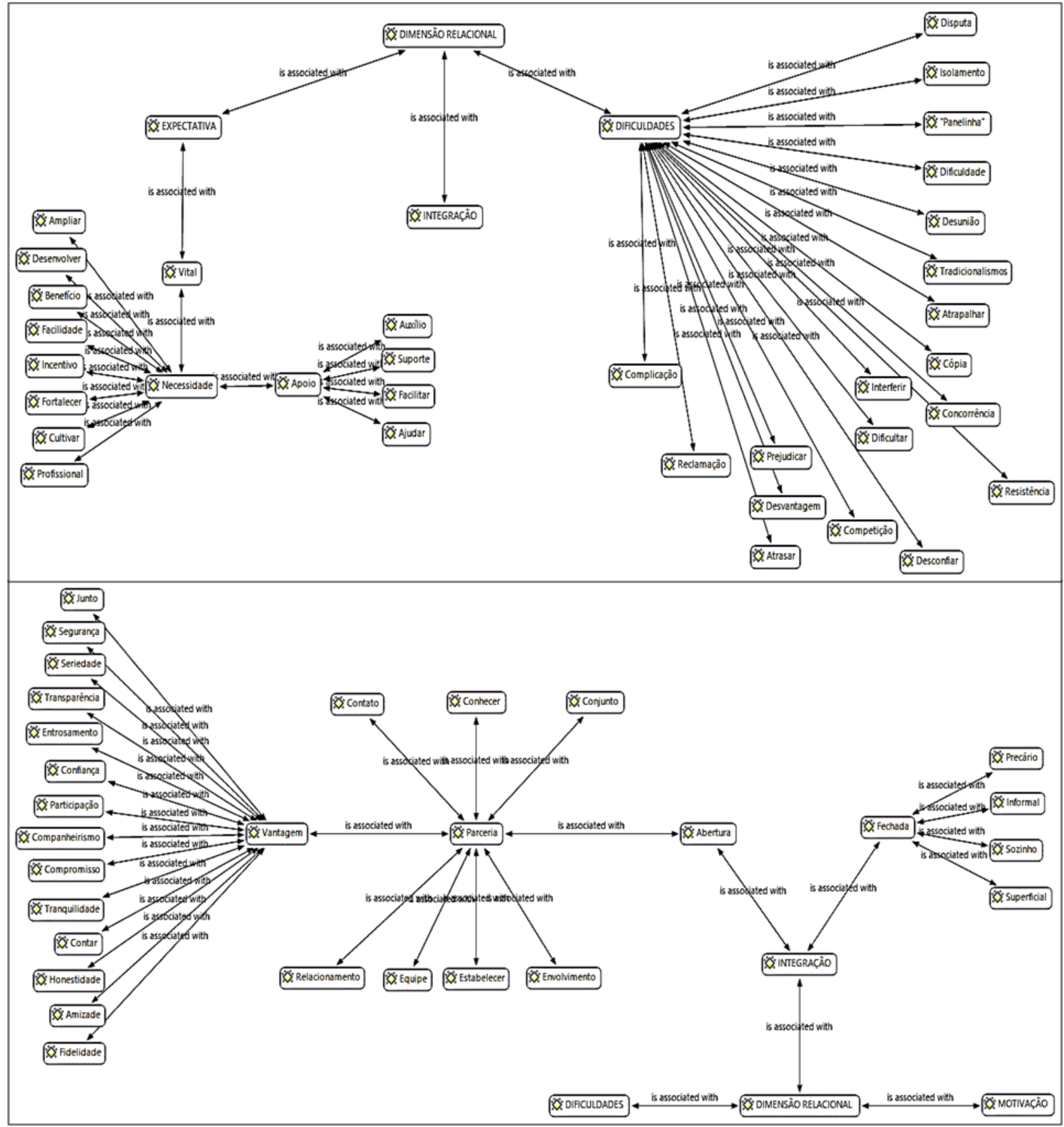

Figura 1 - Grade de análise da Dimensão Relacional no APL de Nova Serrana - MG.

Fonte: Os autores (2015).

$\mathrm{Na}$ Dimensão Cognitiva, por sua vez, constatou-se que a complementaridade entre identidades individuais reforçam os laços de relacionamentos. Assim, apesar de reconhecerem a necessidade de se relacionar fora do contexto do APL e das dificuldades encontradas para o estabelecimento de relações internas, em função da competividade e da desconfiança evidenciada na 
Dimensão Relacional, o conteúdo das entrevistas demonstrou uma melhor fluência das relações intrarregionais. O que se percebe na maioria dos relatos é que o Capital Social fundamenta-se na confiança, na trajetória comum e nas amizades entre os atores sociais.

Entre os recursos compartilhados observa-se o acesso à informação e ao conhecimento, percebidos como ganhos para a empresa, e em termos de resultados, percebe-se o uso de termos como aprendizagem, satisfação, vendas e dinheiro, que também remetem a ganhos para a empresa.

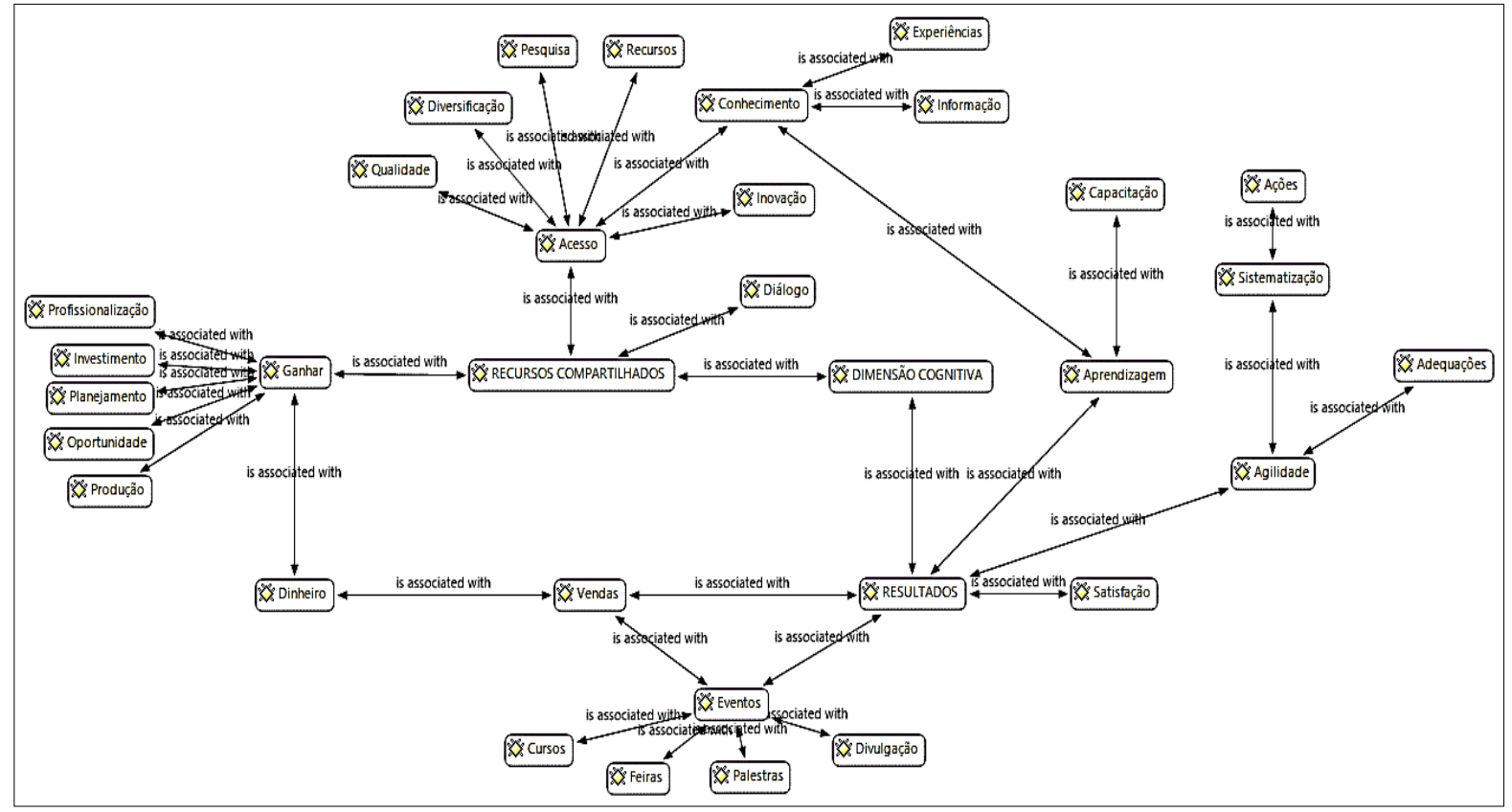

Figura 2 - Grade de análise da Dimensão Cognitiva no APL de Nova Serrana MG.

Fonte: Os autores (2015).

Eu prefiro tratar com quem eu já tenho amizade, acho mais fácil de chegar na pessoa porque a gente já tem um conhecimento um com outro e pensa mais ou menos igual (ENTREVISTADO 05).

Para a relação ser produtiva você tem que ser sempre honesto e justo em qualquer situação [...] Nova Serrana é uma cidade pequena, dá prá fazer muita amizade e das amizades podem surgir parcerias [...] Eu me relaciono mais com os mais íntimos, mais amigos, neles é mais fácil de confiar, né... Quando eles precisam de mim, eu ajudo, e quando eu preciso deles, eles me ajudam também (ENTREVISTADO 07). 
Ao se considerar a Dimensão Estrutural verificou-se, após a confluência dos papéis assumidos por cada ator e da sua localização, que ainda que sejam considerados os dois lócus para estabelecimento de relações (interno e externo) ao arranjo, as relações remanescentes na fala dos entrevistados remetem ao núcleo intrarregional.

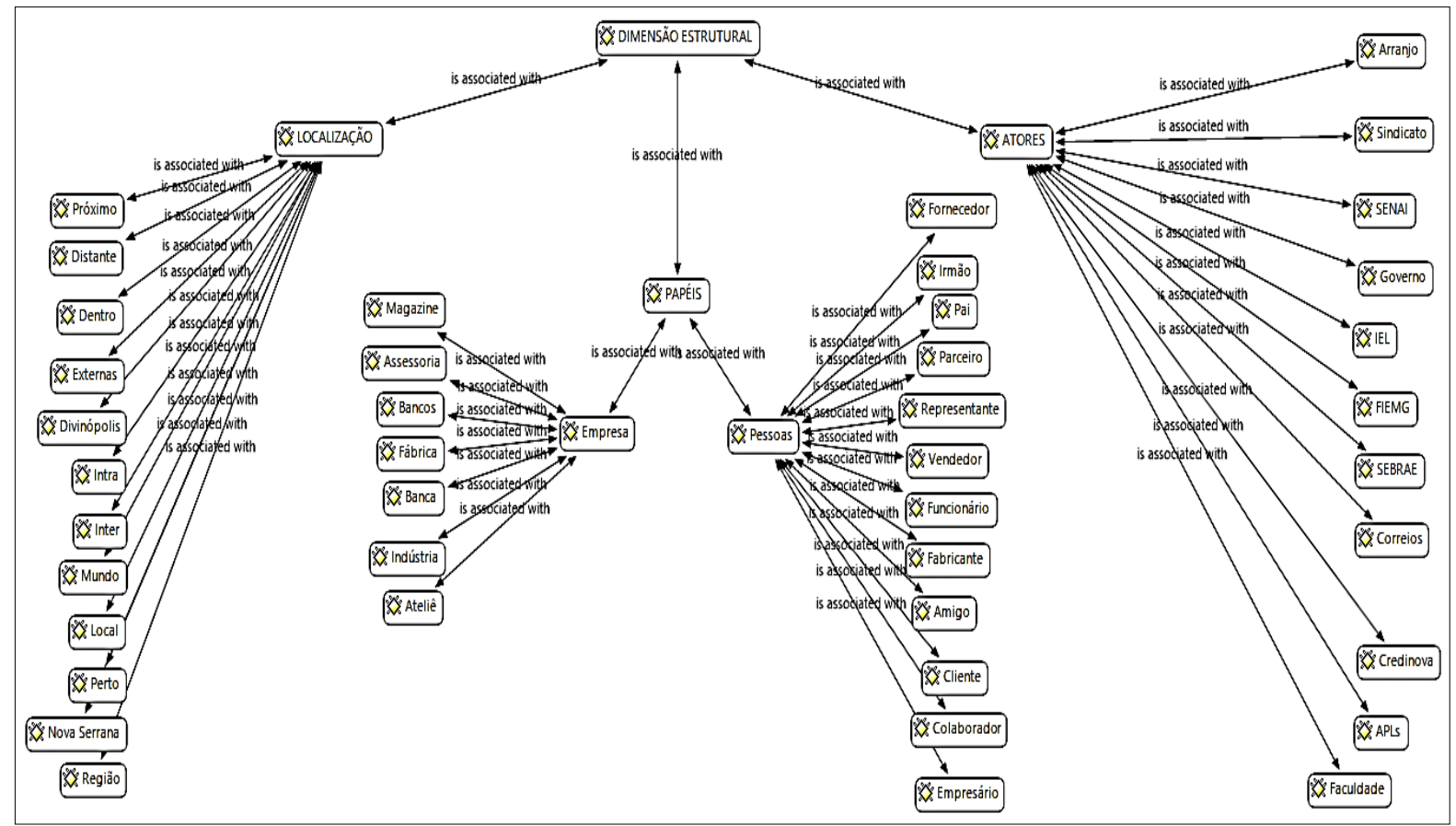

Figura 3 - Grade de análise da Dimensão Estrutural no APL de Nova Serrana - MG.

Fonte: Os autores (2015).

Dentro de Nova Serrana me relaciono mais com os prestadores de serviços que são meus fornecedores e o Sindicato e outras associações que temos também um bom relacionamento, por exemplo, a movimentação financeira da empresa é feita em grande parte na Credinova, já recorremos ao SEBRAE para uma consultoria, já contratei menor aprendiz pelo SENAl, já desenvolvi coleção com modelista da oficina lá do Sindinova, inclusive minha esposa fez um curso de modelagem pelo Sindinova, Oficina de Design; eu acho que mudou demais a realidade da nossa empresa (ENTREVISTADO 07). 


\section{Formação e Desenvolvimento do Capital Social}

Ao se analisar a formação e o desenvolvimento do Capital Social inter e intrarregional, na perspectiva dos atores organizacionais e no arranjo produtivo local de Nova Serrana - MG, percebeu-se, em termos gerais, que o Capital Social estrutura-se conforme a relação de identificação e confiança estabelecida entre os atores. Uma vez estabelecida a relação, os empresários procuram trabalhar valores como transparência e honestidade e, no caso das relações mercantis, além desses, também a pontualidade e a qualidade para manterem e/ou fortalecerem os vínculos nas relações.

Nas relações aqui da empresa, e nas minhas particulares também, primeiro, a gente prioriza a honestidade e a transparência; isso é essencial porque gera confiança para a relação [...] numa relação o que vale mais é a seriedade; sabe essa questão de honrar compromissos? Pois é, nós honramos e gostamos que honrem conosco (ENTREVISTADO 09).

Os entrevistados demonstraram pleno reconhecimento da importância da interação e das trocas sociais para o desenvolvimento de seus negócios. Ainda que não estivessem familiarizados com a terminologia do Capital Social no contexto relacional, foram unânimes em demonstrar interesse em expandir a rede de relacionamentos, aumentando os níveis de recursos que acessam por meio dela, embora uns tenham demonstrado mais interesse e abertura que outros.

Relacionamento é uma influência positiva né, importante demais, por exemplo, não tem como a empresa não se relacionar, ela precisa vender, precisa comprar, tudo depende de alguém ou de alguma empresa (ENTREVISTADO 02).

Esse é o meu negócio, se eu não tiver contato das empresas de que eu dependo para fazer o produto e nem com os clientes que vão me comprar esse produto, não tem porque existir empresa, entende? Por isso, eu entendo que quanto mais relacionamento melhor (ENTREVISTADO 04).

AZEVEDO, A. C.; PARDINI, D. J.; SIMÃO, G. L. Capital social e relacionamentos inter e intrarregionais em arranjos produtivos locais: estudo no APL calçadista de Nova Serrana/ MG. Revista de Empreendedorismo e Gestão de Pequenas Empresas, v.4, n.2, 2015. 
Em termos característicos, o que se apurou foi que as relações inter e intrarregionais se formam e se desenvolvem por critérios distintos, como se pode observar no Quadro 4.

Quadro 4 - Características de formação e desenvolvimento do Capital Social no APL de Nova Serrana - MG.

\begin{tabular}{|c|c|}
\hline INTER-REGIONAL & INTRARREGIONAL \\
\hline $\begin{array}{l}\text { Contatos estabelecidos, geralmente por } \\
\text { representantes e clientes, que são } \\
\text { estreitados (quando conveniente) por meio } \\
\text { de transações mercantis. Tais relações são } \\
\text { valorizadas por facilitarem o acesso a } \\
\text { novidades e, muitas vezes, são acessadas } \\
\text { em períodos característicos, por exemplo, } \\
\text { no lançamento de coleções. A parte, isso } \\
\text { se considera também a prática do } \\
\text { Benchmarking em que atores do núcleo } \\
\text { observam práticas inovadoras e de } \\
\text { sucesso de outros externos ao APL. }\end{array}$ & $\begin{array}{l}\text { Contatos estabelecidos entre amigos e } \\
\text { familiares ou entidades com credenciais } \\
\text { reconhecidas, como Sindinova, SEBRAE e } \\
\text { SENAI. São estruturadas pelos níveis de } \\
\text { confiança existentes e representam } \\
\text { parcerias de apoio para o desenvolvimento } \\
\text { do negócio. }\end{array}$ \\
\hline
\end{tabular}

Fonte: Os autores (2015).

Consideradas as particularidades e o tipo de relações estabelecidas em cada âmbito (externo e interno ao APL), percebe-se na fala dos gestores, que uma empresa não pode escolher se relacionar dentro do arranjo ou fora dele. Ela precisa atuar nos dois contextos, porque eles dão acesso a recursos distintos.

Não tem como escolher ficar só dentro ou só fora do APL. No meu caso, funciona assim: quando eu quero desenvolver coleção, conhecer as tendências e essas coisas, eu viajo, inclusive para a Itália porque é lá que fica a novidade quando se fala de sapato, para vender também meu produto é caro para ficar aqui em Nova Serrana, só que por outro lado eu preciso do APL para prestação de serviço, tem as bancas, têm as injetoras, as ideias estão fora, mas a condição de produzir tá aqui dentro (ENTREVISTADO 03).

\section{Motivações, Expectativas e Justificativas para se Relacionar}

Em relação aos antecedentes (motivações, expectativas e justificativas) pelos quais os atores estabelecem relações internas e externas ao APL, observouse que os atores se relacionam pela necessidade de alcançar determinados recursos. Esses recursos de naturezas física e informacional devem atender a AZEVEDO, A. C.; PARDINI, D. J.; SIMÃO, G. L. Capital social e relacionamentos inter e intrarregionais em arranjos produtivos locais: estudo no APL calçadista de Nova Serrana/ MG. Revista de Empreendedorismo e Gestão de Pequenas Empresas, v.4, n.2, 2015. 
algum propósito previamente estabelecido e dar condições para alcance de algum objetivo específico.

Dois pontos se destacaram nessas circunstâncias de análise: o primeiro refere-se à questão da troca. Os atores entrevistados foram categóricos em afirmar que os relacionamentos só se sustentam por meio do benefício mútuo. Portanto, ambas as partes devem extrair uma positividade da relação estabelecida, caso contrário ela não se justifica. O segundo ponto refere-se ao fato de que todo tipo de relacionamento é valorizado e reconhecido como necessário pelos atores, pois, ao seu tempo, todos se mostram úteis ao desenvolvimento das atividades empresariais, sejam essas operacionais ou estratégicas.

Gosto de bater na tecla de que todos devem ganhar algo com a relação (ENTREVISTADO 01).

Então, assim, no geral, a gente procura sempre oferecer algo em troca, para ser uma mão lavando a outra (ENTREVISTADO 02).

Eu me relaciono prá conseguir mais recurso para minha empresa, qualquer tipo de recurso (ENTREVISTADO 04).

Para cultivar as relações às duas partes tem que ganhar, então a gente procura tá sempre oferecendo algo bom em troca (ENTREVISTADO 07).

Relacionamento é necessidade! Necessidade de produto, necessidade de venda, necessidade de coisas novas, necessidade de dinheiro também, todas as necessidades, no APL e fora dele (ENTREVISTADO 08).

Sempre que busco algum novo parceiro ou uma nova relação, como você diz, o que na verdade estou buscando é algo de que minha empresa necessita, então acho que eu me relaciono mais por causa das necessidades da minha empresa, ou poderia dizer, eu estabeleço relações para atender as necessidades da empresa (ENTREVISTADO 09).

Mas tudo é análise da proposta, se a gente ver que é interessante e lucrativa para os dois lados ganharem, não teria resistência em estreitar um relacionamento ou fazer uma parceria com qualquer empresa aqui da cidade (ENTREVISTADO 10).

AZEVEDO, A. C.; PARDINI, D. J.; SIMÃO, G. L. Capital social e relacionamentos inter e intrarregionais em arranjos produtivos locais: estudo no APL calçadista de Nova Serrana/ MG. Revista de Empreendedorismo e Gestão de Pequenas Empresas, v.4, n.2, 2015. 
Considerando a proposição de distinguir em dois contextos os níveis de observação, o Quadro 5 apresenta um resumo das características das relações internas e externas ao arranjo nesta perspectiva.

Quadro 5 - Motivações, expectativas e justificativas para se relacionar dos empresários do APL de Nova Serrana - MG.

\begin{tabular}{|c|c|}
\hline INTER-REGIONAL & INTRARREGIONAL \\
\hline $\begin{array}{l}\text { Os atores se relacionam fora do APL para } \\
\text { conhecerem práticas inovativas de } \\
\text { desenvolvimento, de fabricação ou de } \\
\text { comercialização de seus produtos. } \\
\text { Esperam alcançar retornos, como } \\
\text { aumento da capacidade produtiva, por } \\
\text { meio do incremento dos processos fabris, } \\
\text { maiores volumes de vendas e maior } \\
\text { reconhecimento e participação da } \\
\text { empresa no mercado. }\end{array}$ & $\begin{array}{l}\text { Os atores se relacionam dentro do APL } \\
\text { para alcançarem benefícios operacionais e } \\
\text { para encontrarem respaldo em algumas de } \\
\text { suas atividades e obrigações, sobretudo } \\
\text { as de cunho legal. O que esperam } \\
\text { alcançar nessas relações são informações } \\
\text { sobre a melhor maneira para agir, } \\
\text { conforme determinado quadro ou acessar } \\
\text { recursos que atuam na resolução de } \\
\text { conflitos momentâneos. Compartilhar } \\
\text { saberes, ter acesso ao que o outro sabe é } \\
\text { uma forma de se investir e reinvestir no } \\
\text { negócio. }\end{array}$ \\
\hline
\end{tabular}

Fonte: Os autores (2015).

Mais uma vez, observa-se que as relações inter-regionais e intrarregionais são originadas de necessidades distintas, sendo que, em função disso, ambas são percebidas como importantes para o desenvolvimento do negócio.

\section{Mobilização, cultivo e utilização do Capital Social nas relações inter e intrarregionais}

Ao propor identificar como os atores mobilizam, utilizam e cultivam o Capital Social para o desenvolvimento de seus negócios no APL de Nova Serrana - MG, compreendeu-se que a interação sempre é intensificada diante de uma maior necessidade.

Os atores são diretivos ao se relacionarem. Assim, se precisam rever um processo produtivo, procuram diálogo com outros fabricantes para a troca de experiências, se precisam aumentar o volume de vendas, procuram clientes e representantes, se necessitam de um amparo diante de uma nova legislação, procuram o Sindicato, se necessitam desenvolver novas coleções, buscam contato

AZEVEDO, A. C.; PARDINI, D. J.; SIMÃO, G. L. Capital social e relacionamentos inter e intrarregionais em arranjos produtivos locais: estudo no APL calçadista de Nova Serrana/ MG. Revista de Empreendedorismo e Gestão de Pequenas Empresas, v.4, n.2, 2015. 
com atores externos, pioneiros nessas ações e também acessam fornecedores para avaliar se terão as condições necessárias para o desenvolvimento e produção dos produtos em questão, e assim sucessivamente.

Aqui dentro a gente tem um relacionamento bom com a Credinova e os outros bancos também, com o SENAI por causa do menor aprendiz, com o próprio Sindinova principalmente pela parte de regulamentação da empresa, normas e legislações, essas coisas, ou, de vez em quando, algum curso ou palestra, quando precisamos, mas é muito raro, acessamos a Prefeitura também, fora isso, nossos clientes e fornecedores são todos de fora de Nova Serrana (ENTREVISTADO 10).

O cultivo do Capital Social é valorizado em função da mutualidade. Sempre oferecer algo em troca, na visão dos atores é uma forma de cultivo do Capital Social, por isso fundamentam-se nos valores já citados anteriormente.

\section{Percepções acerca do APL e da competitividade}

Um dos objetivos desse estudo, ainda que não tenha sido expressamente abordado, refere-se à análise da relação entre a atuação do APL, no APL, e a representatividade dessa atuação em termos de retornos alcançados pelas empresas inseridas no núcleo, na perspectiva dos atores organizacionais. Quando questionados sobre a atuação do APL de Nova Serrana e a representatividade desse núcleo para suas empresas, os posicionamentos dos entrevistados tiveram focos variados.

Percebeu-se um grupo que considera o APL pouco ou nada efetivo, provendo ações em favorecimento de apenas algumas empresas em detrimento de outras. Os empresários que comungam desse posicionamento foram categóricos em afirmar que a inserção no APL e as atitudes tomadas pela entidade gestora do arranjo em nada lhes favorecem.

Não representa muita coisa, nós não participamos muito do APL, nossa participação fica reduzida a uma palestra ou outra. Nós não pertencemos ao grupinho. A fábrica é que tem que ficar correndo atrás, se precisa de alguma coisa. E olha que nós pagamos a

AZEVEDO, A. C.; PARDINI, D. J.; SIMÃO, G. L. Capital social e relacionamentos inter e intrarregionais em arranjos produtivos locais: estudo no APL calçadista de Nova Serrana/ MG. Revista de Empreendedorismo e Gestão de Pequenas Empresas, v.4, n.2, 2015. 
mensalidade do Sindinova certinho, mas é dinheiro jogado fora. O APL hoje, infelizmente, não tem representatividade nenhuma para a empresa [...] Lógico que quem tá lá dentro tem acesso às coisas primeiro, mas eles deviam mandar informações também para as pequenas empresas [...] eles se preocupam só com um grupo de empresas, sempre as mesmas, as maiores, e fica tudo entre eles, uma verdadeira panelinha (ENTREVISTADO 02).

Depende de que "ponto" do APL se analisa, mas, em geral, a atuação e, por consequência, os benefícios gerados pelo "APL" é para poucos. Atualmente, para a minha empresa, a atuação do APL não representa muito, porque eu não faço parte do grupo dos "cabeças" (ENTREVISTADO 06).

Não sei ao certo, mas acho que o APL deveria ser algo maior, que olhasse mais pelas empresas, por todas as empresas, da mesma forma (ENTREVISTADO 10).

Existem aqueles que acreditam nos benefícios do arranjo produtivo, embora não o considerem integralmente efetivo, mas passível de melhorias. Da mesma forma, há alguns empresários que consideram o APL positivo, porém julgam que não cumpre seus propósitos, principalmente em função das próprias empresas. Esses empresários consideram que o APL de Nova Serrana se desenvolve conforme o contexto lhe permite e avaliam que a adequação, mesmo que faça o núcleo perder algumas de suas propriedades características, é um requisito necessário para que ele se mantenha.

O APL de Nova Serrana cresceu muito nos últimos anos, mas ainda tem muito o que desenvolver, principalmente nas atividades acessórias ao setor calçadista como a fabricação de matériasprimas e máquinas e equipamentos, mas estamos no caminho certo (ENTREVISTADO 01).

É muito importante para nossa empresa, serve de um apoio em diversos aspectos, produtivos, financeiros e administrativos (ENTREVISTADO 03).

Vejo que a cidade ganhou, mas, às vezes, para o projeto APL mesmo, pela sua idealização; aí ele foge um pouquinho, mas ganhos ele traz, com certeza. Talvez se eles readequarem e tá bom também, aí eu já num sei como que tá. Porque hoje eu já não estou tão atuante no sindicato como eu já fui anteriormente quando cheguei até a ser membro da diretoria; pelo pouco conhecimento que tenho, para o APL funcionar bem, ele tem que ser reorganizado (ENTREVISTADO 09).

AZEVEDO, A. C.; PARDINI, D. J.; SIMÃO, G. L. Capital social e relacionamentos inter e intrarregionais em arranjos produtivos locais: estudo no APL calçadista de Nova Serrana/ MG. Revista de Empreendedorismo e Gestão de Pequenas Empresas, v.4, n.2, 2015. 
Prosseguindo o mapeamento das posições em relação ao APL, há os que se mostram indiferentes ao arranjo, gozam de um ou de outro benefício, mas não demonstram indícios de uma interação mais frequente, sobretudo em função da desconfiança. Outro ponto de observação relevante nesse fragmento refere-se à questão de que a maioria dos atores entrevistados desconhece parcial ou integralmente os aspectos característicos e direcionadores de um APL, ou seja, mal sabem do que se trata o arranjo.

Eu sou pouco participativo no Sindinova, mas pago minha mensalidade em dia e sempre que precisei, eles me atenderam. Eu não conheço ao certo o propósito do $A P L_{2}$ mas acho que, de certa forma, ele não é tudo o que dizem. Mas isso prá mim é indiferente. Como fico mais distante, as dificuldades que eu tenho de começar relações no APL é realmente de confiar nos outros empresários e até no próprio sindicato que é gerenciado também por empresários (ENTREVISTADO 04).

Em contrapartida aos posicionamentos apresentados até agora, há empresários que se posicionam como defensores do APL e avaliam positivamente as ações promovidas no núcleo. Esses empresários criticam as empresas que não são participativas, transferindo a estas a responsabilidade pela não interação e promoção das barreiras de exclusão e isolamento que prejudicam o desempenho do arranjo.

O APL recebe muita reclamação, mas é de gente que não participa. Fala muito que tem um grupinho, mas é porque os próprios fabricantes não querem participar, não mostram interesse em se envolverem [...] O sindicato só é bom para quem realmente participa, senão perde o sentido; a minha empresa se reestruturou completamente depois de uma oficina de Design oferecida em 2004 pelo Sindinova, desde essa época nunca mais nos afastamos (ENTREVISTADO 07).

Agora uma coisa eu falo, a maior parte das empresas, mas a maioria mesmo, não participa das atividades do Sindicato, por exemplo, uma discussão, uma votação ou algo assim, a não ser quando estão encurraladas como aconteceu recente agora com a NR12, eu presenciei isso, uma pesquisa que a gente envia normalmente em uma situação normal, 10 empresas respondem, com a NR12 mais de 200 deram retorno em dois dias. Então, assim dá prá ver a questão do egoísmo, a pessoa só participa diante de uma necessidade extrema, as pessoas só reclamam do Sindicato,

AZEVEDO, A. C.; PARDINI, D. J.; SIMÃO, G. L. Capital social e relacionamentos inter e intrarregionais em arranjos produtivos locais: estudo no APL calçadista de Nova Serrana/ MG. Revista de Empreendedorismo e Gestão de Pequenas Empresas, v.4, n.2, 2015. 
mas não entendem que eles são o Sindicato [...] Tem muita gente prá reclamar e quase ninguém prá fazer. Ninguém vai dar sugestão ou leva uma demanda prá discussão, as pessoas não fazem isso, por exemplo, poucos sabem que o sindicato tem uma assessoria jurídica, as pessoas não sabem o que o Sindicato oferece, passam dificuldades, ficam na delas, reclamam, mas não vão lá ver o que o Sindicato pode oferecer, querem solução imediata mas não cooperam. Eu sei de gente que fala que o Sindicato é uma panelinha, mas eu discordo completamente, na verdade o Sindicato só é efetivo prá quem realmente procura o Sindicato; gente que só quer ganhar, mas não quer oferecer nada em troca, realmente não percebe benefícios (ENTREVISTADO 09).

O empresário afirma que a maior dificuldade encontrada pelo sindicato no atendimento às empresas refere-se à diversidade das indústrias que compõem o arranjo. Apesar de produzirem produtos semelhantes e dos elevados níveis de concorrência interna, a maior dificuldade é gerenciar o perfil heterogêneo das empresas que apresentam demandas diferentes: uma fábrica com 400 funcionários tem necessidades distintas de uma fábrica com 10 funcionários. No entanto, o sindicato é único para prover ações em atendimento às duas empresas.

De forma geral, ao se avaliar as dificuldades para se estabelecer relações dentro desse núcleo e também por meio dele, percebeu-se, com mais relevância, a questão da ausência de confiança entre os membros. Conforme já abordado em análise anterior, os atores apresentam grande dificuldade em confiar uns nos outros e em função disso, terminam por se isolarem e não desenvolverem mecanismos de interatividade e cooperação, atitude que foge completamente aos propósitos de um arranjo produtivo.

Eu acho que é uma dificuldade grande, principalmente por ser uma região pequena; tem muita disputa entre os fabricantes, todos querem se sobressair aos outros. Não importa em quem se tá pisando, o negócio é ganhar, só competindo. Ninguém quer saber de cooperar e isso trava demais o Sindicato, o desenvolvimento do APL, né, de uma maneira geral (ENTREVISTADO 08).

Contudo, nem tudo parece estar perdido. Apesar da desconfiança e das dificuldades no estabelecimento das relações, a maneira como alguns dos empresários se expressam indica, de certa forma, vontade e interesse no desenvolvimento de relações saudáveis e cooperativas, como verificado na fala do

AZEVEDO, A. C.; PARDINI, D. J.; SIMÃO, G. L. Capital social e relacionamentos inter e intrarregionais em arranjos produtivos locais: estudo no APL calçadista de Nova Serrana/ MG. Revista de Empreendedorismo e Gestão de Pequenas Empresas, v.4, n.2, 2015. 
Entrevistado 05. Em suma, relatos dessa dimensão podem indicar vontade dos empresários, no sentido de se construir Capital Social para o APL como um todo.

Dentro do APL, uma dificuldade a ser destacada é certo isolamento de todos, uma não abertura para trocas de experiências e auxílio mútuo, mas eu creio que isso pudesse ser resolvido, se fôssemos mais parceiros uns dos outros (ENTREVISTADO 05).

Apenas dois dos entrevistados avaliaram o APL positivamente em relação aos benefícios da representatividade coletiva, conforme se percebe nos fragmentos a seguir:

O APL, o Sindicato em si, tomando frente dos relacionamentos com o governo é muito bom para as empresas, por exemplo, a questão do RET, se a gente não estivesse no APL, a gente não teria o RET. Então, assim, eu acho que o APL realmente fortalece, torna todas as empresas do polo mais fortes (ENTREVISTADO 09)

O maior benefício do APL é que a cidade fica conhecida como a capital do calçado. E isso gera divulgação no mercado. Os clientes chegam até Nova Serrana buscando calçados baratos, produção em larga escala e às vezes nas feiras ocasionam uma grande movimentação na cidade. A concentração, né, o grande número de empresas chama a atenção para cidade e trás compradores, pessoas interessadas; com isso, as empresas que estão instaladas aqui e que tem preparo para atender bem o mercado acabam se beneficiando. Então, eu posso dizer que o APL é importante pela concentração de empresas do mesmo ramo (ENTREVISTADO 10).

Com relação à competitividade, em âmbito geral, o que se percebeu é que os empresários reconhecem os benefícios do $\mathrm{APL}$, mas não reconhecem a promoção de vantagem competitiva, por entenderem que o $A P L$ não foi ainda plenamente concebido e implantado na realidade de Nova Serrana. Isso é possível observar nas pontuações do Entrevistado 09.

Só que hoje eu vejo assim, Nova Serrana antes do Sindinova e do APL era pior, nós ganhamos com essa sistematização, mas precisa melhorar mais, se a intenção for vantagem competitiva [...] infelizmente Nova Serrana tem uma condição muito desleal, e a falta de preparo de alguns empresários acabam atrapalhando o desenvolvimento de todos [...] Na minha opinião o sentido do APL, na prática, não tá acontecendo dentro do projeto proposto no início

AZEVEDO, A. C.; PARDINI, D. J.; SIMÃO, G. L. Capital social e relacionamentos inter e intrarregionais em arranjos produtivos locais: estudo no APL calçadista de Nova Serrana/ MG. Revista de Empreendedorismo e Gestão de Pequenas Empresas, v.4, n.2, 2015. 
[...] Existe ações que tem lá sua efetividade, mas na concepção de APL mesmo eu acho que ainda tá fora. Mas eu prefiro acreditar que ele ficou assim por adaptação ao cenário local mesmo ele foi modificado para a cidade. Falta entrosamento e participação das pessoas, das empresas. Mas o Sindicato é atuante trabalha sim como um suporte para as empresas o que atende ao projeto do arranjo produtivo aí, com palestras, treinamentos, e várias situações desse tipo, mas só isso não é competitividade, pelo menos não para mim (ENTREVISTADO 09).

Nesta vertente, ao se levantar os recursos que são acessados dentro do núcleo, percebe-se em maior escala aqueles de natureza informacional e profissionalizante, e o Sindinova, de forma geral, atua como órgão de apoio às ações empresariais.

Hoje, o APL é muito significativo prá nós, em termos de planejamento, representatividade e capacitação (ENTREVISTADO 07).

Mas, de qualquer forma, as empresas ganharam em termos de aprendizagem, capacitação, cursos. Eu vejo assim que Nova Serrana, antes do APL e depois do APL [...] A proposta do APL, nós ganhamos com ele, a questão de profissionalização das empresas de Nova Serrana, o trabalho feito para o grupo de Nova Serrana feito para o arranjo produtivo aqui, o trabalho desenvolvido pelo sindicato com esse pessoal aí, FIEMG, IEL, ajudou demais Nova Serrana, só que às vezes não da forma que o APL queria que fosse [...] principalmente na ideia do APL nessa questão de fortalecer competitividade (ENTREVISTADO 09).

[...] vez ou outra, assistimos alguma palestra ou capacitação no Sindicato ou procuramos a FIEMG, por causa do menor aprendiz, mas nada além disso (ENTREVISTADO 10)

Conforme a literatura (AMATO NETO, 2000; ALBAGLI; MACIEL, 2003; LASTRES; CASSIOLATO, 2005; SOUZA FILHO et al., 2013), a atuação das empresas de um APL será mais eficaz quanto mais elas forem capazes de explorar as potenciais sinergias decorrentes de sua proximidade geográfica e da similaridade de seus processos operacionais.

É possível observar que a relativa carência de acumulação de Capital Social no APL está associada à não construção de relações fundamentadas nos critérios de cooperação condizentes aos objetivos de um arranjo produtivo. Assim,

AZEVEDO, A. C.; PARDINI, D. J.; SIMÃO, G. L. Capital social e relacionamentos inter e intrarregionais em arranjos produtivos locais: estudo no APL calçadista de Nova Serrana/ MG. Revista de Empreendedorismo e Gestão de Pequenas Empresas, v.4, n.2, 2015. 
falta às empresas do APL de Nova Serrana - MG, bem como à entidade gestora do arranjo, decisões e atitudes para iniciar e desenvolver relacionamentos que assegurem e desenvolvam seu Capital Social.

Acredita-se que a situação atual é passível de ser contornada, desde que haja uma mudança significativa nas relações inter-regionais, assim como também se acredita que a confiança possa ser adquirida e construída após um período de tempo, por meio de contínuas experiências positivas. Mas isso precisa começar por alguém.

\section{Considerações finais}

O Capital Social de uma empresa refere-se à sua capacidade de acessar recursos, apoios e relações para o desenvolvimento de suas atividades, empreendimentos e solução de problemas. A atividade de construção de Capital Social tem como primícias, o fortalecimento da dinâmica das relações sociais, pois se associa à natureza e à qualidade dos relacionamentos dentro ou fora de um núcleo comum, como é o caso dos Arranjos Produtivos. Nesse sentido, o Capital Social é percebido tanto como a cola que assegura tal interação, como o lubrificante que ajuda os membros da sociedade a se relacionarem.

Os empresários do Arranjo Produtivo Calçadista de Nova Serrana - MG demonstraram reconhecer o valor das práticas sociais e relacionais, e as utilizam em benefício de seus negócios. Contudo, esbarram em questões determinantes, como a ausência de níveis satisfatórios de confiança para o estabelecimento das relações.

O que se percebeu foi que os atores se relacionam por propósitos claros e previamente definidos, sempre com o intuito de acessar determinados recursos, sejam eles de natureza física ou informacional, e contemplam que na interação deve haver mutualidade, com ganhos auferidos por ambas as partes. Há, por parte dos próprios atores, o reconhecimento de que é necessário estabelecer relações de distintas naturezas e intensidade de vínculos, dentro e fora do arranjo produtivo. Nessas circunstâncias, a variação se dá conforme a necessidade de acesso. 
Ao se considerar a realidade do APL de Nova Serrana, percebeu-se que a inserção em um Arranjo Produtivo por si só não é representativa de interação e proveniente de recursos relacionais. Pelo contrário, as dificuldades em se estabelecer relações dentro desses núcleos são percebidas em âmbito geral, sendo a principal delas as posturas individualistas e introspectivas fomentadas pelos elevados níveis de desconfiança. Se o fato de estarem inseridas em um APL favorece a atuação das empresas, é algo que parece estar condicionado à participação e aos níveis de integração que elas possuem no grupo.

O que se pode dizer em termos de efetividade é que o APL de Nova Serrana necessita se aprimorar de forma a prover, de maneira mais eficiente, o intercâmbio de experiências exitosas e recursos entre as empresas, e fomentar práticas integrativas que resgatem valores, como a confiança, resultando em novas parcerias e oportunidades de acesso a mais recursos disponíveis. Ainda que subjetivamente, percebeu-se, na fala dos atores, que eles anseiam por tais adequações.

No que concerne às limitações do estudo em termos teóricos e operacionais, é preciso destacar: o universo reduzido de atores que puderam ser acessados para as entrevistas; ausência de demais atores representativos na composição amostral (clientes, fornecedores, entidades gestoras), por questões de tempo e custo, e ausência de uma análise sociométrica em relação à dimensão estrutural.

No que tange aos aspectos metodológicos, a pesquisa puramente qualitativa apresenta seus opositores na academia, sobretudo por seu caráter pessoal e subjetivo. Contudo, respeitada a proposta deste estudo, a pesquisa qualitativa foi percebida como facilitadora da compreensão da atividade humana. Assim, apesar desses aspectos limitantes, o percurso metodológico seguido foi o que pareceu mais adequado aos objetivos propostos.

Considerando as conclusões precedentes, foram levantadas algumas sugestões para o prosseguimento de estudos nesta temática, dentre as quais se destacam: (i) aprofundamento de estudos estruturais que requerem um mapeamento efetivo das redes de contatos dos atores estudados; (ii) incorporação de atores diversificados para composição amostral e ampliação do número de 
entrevistas realizadas, a fim de capturar com maior fidelidade o processo de desenvolvimento das relações dentro do arranjo e fora dele; (iii) realização de um estudo de casos múltiplos, comparando-se o APL de Nova Serrana - MG com outros APLs, para ampliar conhecimentos sobre a dinâmica relacional nos arranjos; e (iv) utilização de métodos mistos para mapeamento e aferição dos níveis de Capital Social presentes no Arranjo Produtivo de Nova Serrana - MG.

Por fim, espera-se ter contribuído para o avanço do conhecimento acerca do tema proposto, mediante a ampliação dos recentes estudos sobre a utilização do Capital Social como propulsor de vantagem competitiva para os atores organizacionais.

A expectativa, por conseguinte, é a de que o estudo tenha despertado 0 interesse das diversas instituições presentes no arranjo, empresas, entidades gestoras, fornecedores, prestadores de serviço e comunidade em geral, de forma a reconhecerem a necessidade de reavaliar as práticas relacionais oriundas desse núcleo e desenvolverem mecanismos de promoção de confiança, parceria e interação. Afinal, a prática social, apoiada nos valores corretos, conforme determinados pela Teoria do Capital Social, só tem a favorecer o desempenho competitivo das empresas, dentro e fora dos arranjos produtivos locais.

\section{Referências:}

ADLER, P.; KWON, S. Social Capital: Prospects for a new concept. Academy of Management Review, v. 27, n 1, p. 17-40, 2002.

ALBAGLI, S.; MACIEL, M. L. Capital Social e desenvolvimento local. In: LASTRES, H. M. M.; CASSIOLATO, J. E.; MACIEL, M. L. Pequena empresa: cooperação e desenvolvimento local. Rio de Janeiro: Relume Dumará, 2003. p. 423-440.

AMARAL FILHO, J. É negócio ser pequeno, mas em grupo; desenvolvimento em debate: painéis do desenvolvimento brasileiro. Rio de Janeiro: BNDES, 2002.

AMATO NETO, J. Redes de Cooperação Produtiva e Clusters Regionais. São Paulo: Atlas, 2000.

AMORIM, M. Cluster, como estratégia de desenvolvimento industrial no Ceará. Fortaleza, Ceará: Banco do Nordeste, 1998. 
BARDIN, L. Análise de conteúdo. Lisboa: Edições 70, 2010.

CASTELLS, M. A Era da Informação: Economia, Sociedade e Cultura. 2 ed. Fundação Calouste Gulbenkian: Lisboa, 2005.

CRESWELL, J. W. Projeto de pesquisa: métodos qualitativo, quantitativo e misto. 3 ed. Porto Alegre: Artmed/Bookman, 2010.

CUNHA, J. A. C; PASSADOR, J. L.; PASSADOR, C. S. A presença de agentes intermediadores na formação de redes interorganizacionais: uma análise sob a perspectiva temporal. Cad. EBAPE.BR, v.10, n. 1, p. 109-128, 2012.

FERRAZ, S. F. S.; GOBB, R. L.; LIMA, T. C. B. de. Arranjos produtivos locais na perspectiva da teoria do Capital Social: um estudo no cluster moveleiro de marco (CE). Contextus - Revista Contemporânea de Economia e Gestão, v. 9, n. 2, p. 79-95, 2011.

FERREIRA, I. R. C.; VOSGERAU, D. S. R.; MOYSES, S. J.; MOYSES, S. T.. Diplomas Normativos do Programa Saúde na Escola: análise de conteúdo associada à ferramenta ATLAS TI. Ciência \& Saúde Coletiva, v. 17, n. 12, p. 3385-3398, 2012.

FLICK, U. Introdução à pesquisa qualitativa. 3 ed. Porto Alegre: Artmed, 2009.

GOBB, R. L. Cooperação e Confiança em um APL Moveleiro: Um Estudo à Luz do Capital Social e das Redes Interorganizacionais. In: XXXIV ENCONTRO NACIONAL DOS PROGRAMAS DE PÓS-GRADUAÇÃO EM ADMINISTRAÇÃO ENANPAD, 34, 2010. Rio de Janeiro, Anais... Rio de Janeiro: ANPAD, 2010.

GRANOVETTER, M. The Strenght of Weak Ties. The American Journal of Sociology, v. 78, n.6, p. 1360-1380, 1973.

LASTRES, H. M. M.; CASSIOLATO, J. E. Sistemas de inovação e desenvolvimento as implicações de política. São Paulo em Perspectiva, v.19, n. 1, p. 34-45, 2005.

LEITE, R., LOPES, H. E. G.; SILVA, S. A estratégia em relacionamentos coopetitivos: um estudo do arranjo produtivo de Nova Serrana. RBGN Revista Brasileira de Gestão de Negócios. v.11, n. 30, p. 65-78, 2009. 
LIN, N. Building a theory of social capital. In: LIN, N.; COOK, K.; BURT, S. R. (ed.) Social Capital: Theory and Research. New York: Aldine de Gruyter, 2001. p. 3-30.

LUNDVALL, B. A. Innovation as an interactive process: from user-producer interaction to the national system of innovation. In: DOSI, G.; PAVITT, K.; SOETE, L. Technical change and economic theory. London: Pinter Publishers, 1988.

MARCONATTO D.; PEDROZO, E. A. Capital Social: uma visão integrada. In: XXXV ENCONTRO NACIONAL DOS PROGRAMAS DE PÓS-GRADUAÇÃO EM ADMINISTRAÇÃO - ENANPAD, 35, 2011. Rio de Janeiro, Anais... Rio de Janeiro: ANPAD, 2011.

MARTELETO, R. M.; SILVA, A. B. O. Redes e Capital Social: o enfoque da informação para o desenvolvimento local. Ciência da Informação. Brasília, v. 33, n. 3, p.41-49, 2004.

MORE, J. D.; VALLE, M. R.; VILLELA, L. E. Modelo Fuzzy para Avaliação de Influência de Fatores Endógenos e Exógenos no Desenvolvimento de um APL Aplicação no Caso de Cabo Frio-RJ. In: XXXI ENCONTRO NACIONAL DOS PROGRAMAS DE PÓS-GRADUAÇÃO EM ADMINISTRAÇÃO - ENANPAD, 31, 2007, Rio de Janeiro, Anais... Rio de Janeiro: ANPAD, 2007.

NAHAPIET, J.; GHOSHAL, S. Social capital, intellectual capital and the organizational advantage. Academy of Management Review, v. 23, n. 2, p. 242266, 1998.

PORTES, A. Social capital: Its origins and applications in modern sociology. Annual Review of Sociology, v. 24, p. 1-24, 1998.

REGIS, H. P. Construção social de uma rede informal de mentoria nas incubadoras de base tecnológica do Recife. 196f. Tese (Doutorado) - Programa de Pós Graduação em Administração-PROPAD, Universidade Federal de Pernambuco, Recife, 2005.

RODRIGUES, S. B.; CHILD, J. Building social capital for internationalization. Revista de Administração Contemporânea. v.16, n. 1, p. 23-38, 2012.

SOUZA FILHO, O. V.; SILVEIRA, R. Z.; CARRIERI, A. P.; TEIXEIRA, J. C. Um arranjo produtivo em xeque: campo, habitus e capital simbólico em um Arranjo Produtivo Local moveleiro em Minas Gerais. Revista de Administração, v. 48, n. 4, p. 671-687, 2013.

AZEVEDO, A. C.; PARDINI, D. J.; SIMÃO, G. L. Capital social e relacionamentos inter e intrarregionais em arranjos produtivos locais: estudo no APL calçadista de Nova Serrana/ MG. Revista de Empreendedorismo e Gestão de Pequenas Empresas, v.4, n.2, 2015. 
SUGAHARA, C. R.; VERGUEIRO, W. C. S. Redes sociais: um olhar sobre a dinâmica da informação na rede (APL) Arranjo Produtivo Local Têxtil, de Americana - São Paulo. 1 ed. São Paulo: Editora Sociologia e Política, 2011.

VALE, G. M. V. Territórios vitoriosos: o papel das redes organizacionais. Rio de Janeiro: Editora Garamond Ltda., 2007.

WEGNER, D., MAEHLER, A. E. Capital Social e Capacidade Absortiva: Influências no Desempenho de Empresas Participantes de Redes Interorganizacionais. In: VI ENCONTRO DE ESTUDOS ORGANIZACIONAIS DA ANPAD - EnEO, 6, 2010. Florianópolis, Anais... Rio de Janeiro: EnEO, 2010.

WEGNER, D.; MAEHLER, A. E. Desempenho de empresas participantes de redes interorganizacionais: analisando a influência do Capital Social e da capacidade absortiva. Revista Gestão \& Planejamento, v. 13, n. 2, p. 191-211, 2012.

YIN, Robert. K. Estudo de caso. 2 ed. Porto Alegre: Bookman, 2001. 